\title{
Heat Stress Impacts Immune Status in Cows Across the Life Cycle
}

\author{
Geoffrey E. Dahl ${ }^{1 * t}$, Sha Tao $^{2 t}$ and Jimena Laporta ${ }^{1+}$ \\ ${ }^{1}$ Department of Animal Sciences, University of Florida, Gainesville, FL, United States, ${ }^{2}$ Department of Animal and Dairy \\ Science, University of Georgia, Tifton, GA, United States
}

\section{OPEN ACCESS}

Edited by:

Michael Kogut

United States Department of

Agriculture, United States

Reviewed by:

Hans-Joachim Schuberth, University of Veterinary Medicine

Hannover, Germany Christi Swaggerty,

United States Department of

Agriculture (USDA), United States

${ }^{*}$ Correspondence: Geoffrey E. Dah gdahl@ufl.edu

†These authors have contributed equally to this work

Specialty section: This article was submitted to Veterinary Infectious Diseases, a section of the journal Frontiers in Veterinary Science

Received: 11 November 2019 Accepted: 17 February 2020

Published: 06 March 2020

Citation:

Dahl GE, Tao S and Laporta J (2020) Heat Stress Impacts Immune Status in

Cows Across the Life Cycle. Front. Vet. Sci. 7:116. doi: 10.3389/fvets.2020.00116
Heat stress has a myriad of effects on dairy cattle across the life cycle. Whereas, the most commonly recognized impacts are associated with production responses, emerging evidence indicates that heat stress profoundly alters the immune response of calves and cows, from the prenatal stage through lactation. For example, in utero heat stress reduces passive immune transfer regardless of colostrum source, relative to normothermic conditions in late gestation. Dry cows exposed to heat stress have lower immunoglobulin responses to ovalbumin vaccination, but this effect dissipates with cooling following parturition. Conversely, cows under heat stress when dry exhibit carryover effects on the innate arm of the immune system in early lactation. In this paper we review the effects of heat stress throughout the life cycle of the dairy cow, with particular emphasis on the impact of heat stress during late gestation on the cow and the developing fetus, both before and after parturition. In addition, the impact of altered immune status under heat stress on other physiological systems, especially those supporting milk production, are considered. Finally, management interventions to prevent and reverse the effect of heat stress are presented.

Keywords: disease, dry period, calves, heifers, lactation

\section{INTRODUCTION}

Whereas, a number of environmental factors can affect animal immune status and productivity, heat stress dominates as a negative influence on animal health performance around the globe. As global temperatures rise, heat stress potential, both absolute, and from a duration perspective, is increasing. Heat stress occurs when a cow's ability to disperse heat produced through normal metabolism is compromised, usually as a result of ambient temperature exceeding the thermoneutral zone (TNZ), which is defined as the temperature range wherein an animal maintains normal body temperature without altering metabolic heat production or employing evaporative heat loss mechanisms. Because evaporative heat loss is affected by water vapor differences in the environment, relative humidity can also have profound effects on an animal's ability to rid the body of heat, and thus affect heat stress. Indeed, as ambient temperature and humidity increase, heat stress becomes more severe. One of the most effective indicators of the potential for heat stress, therefore, is the temperature-humidity index (THI), which accounts for the impact of rising humidity diminishing the capacity for heat loss. Of course, heat load can also increase with exposure to radiant energy (i.e., sun exposure), and so a lack of shading with a high THI can exacerbate heat stress.

Homeotherms maintain body temperature by ensuring equilibrium between heat gain and heat loss (1). Under heat stress conditions, animals acclimate to environmental heat by decreasing heat gain and increasing heat loss (1). To reduce the heat load, heat-stressed cattle 
decrease metabolic heat production by reducing feed intake and production, such as milk yield, and growth. Heat exchange between the animal and surrounding environment is altered in order to dissipate heat. Animals exchange heat with the environment through sensible heat transfer including radiation, convection and conduction and insensible or latent heat loss by evaporation $(2,3)$. The magnitude of sensible heat exchange is dependent on temperature difference between body surface of the animal and surrounding environment, and evaporative heat loss is temperature independent and associated with humidity. Radiation is of importance in animals raised in open lots and on pasture, as they receive substantial amount of heat from solar radiation during the day and dissipate heat to the cooler sky at night (1). However, for animals housed in barns or buildings, heat exchange through radiation is minimized. For example, in typical free-stall dairy barns in Florida, black globe temperature is similar to dry bulb temperature indicating that physical shade blocks most of the solar radiation (4). In response to environmental heat stress, cutaneous blood flow of cattle is increased which brings heat from the body core to the periphery and enhances heat loss through sensible heat loss (5). However, as environmental temperature increases, sensible heat exchange is minimized due to the negative temperature difference between environment and body surface and, therefore, evaporative heat loss plays the dominant role in thermoregulation of animals (6). As ambient temperature increases, evaporative heat loss is initially mediated by sweating and is then followed by increased respiratory heat loss as heat stress becomes more severe (7). As the heat load on an animal increases, various physiological systems are affected to reduce heat production and increase heat loss in an effort to maintain normal core temperature. Elevated core temperature and respiration rate are hallmarks of heat stress in cattle and other species, and are easily quantified with rectal, vaginal or ruminal probes (core temperature), and observation of inspiration and expiration via flank movements, respectively. Whereas, monitoring the impact of heat exposure is a useful management tool, there is growing evidence that the effects of heat stress can persist after the insult is removed, particularly in the developing fetus. The objective of this paper is to review the effects of heat stress on immune function and status in cows across the life cycle and provide suggestions for managing these effects to improve immune and, potentially, disease outcomes.

\section{DEVELOPMENT OF THE IMMUNE SYSTEM IN THE BOVINE}

A robust and well-developed immune system is crucial to overcome the multitude of challenges that livestock are exposed to under the prevalent intensive production systems (8). Establishment of a functional and mature immune system in all mammals requires a sequential series of highly coordinated developmental events that begin early in embryonic/fetal life and continue through the early postnatal period (9). Development of the bovine immune system begins with conception (embryonic stage), continues progressively in utero (fetal stage) and reaches maturity at $\sim 6$ months after birth
(10). Early studies examining bovine fetuses at different stages of development revealed that primary lymphoid organs of the immune system are present early in fetal development. The thymus is structurally present at 42 days of gestation, the spleen at 55 days, and peripheral lymph nodes are present at 60 days (11). As the fetus develops in utero two immune mechanisms develop: acquired (dependent on antigen recognition) and innate (independent of those recognition events). These mechanisms often act independently, however, when they act in combination, they provide greater protection than either system can alone. Ultimately, all the cells that will provide defense mechanisms originate from the same pluripotent hemopoietic stem cells.

The innate immune response mediated by phagocytic cells (neutrophils and macrophages) does not develop fully until late gestation, and in fact there is a decline in its functional capacity as gestation approaches because of the increase in fetal cortisol concentrations with the impending parturition (12). Humoral elements, such as complement proteins, are present in newborn calves; however, the levels and activity at birth are approximately reduced by half compared to those of adult cows. Also, interferon can be induced in a fetus as early as 60 days of gestation, and all the cellular components of the acquired immune response are present in fetal calves $(13,14)$. More specifically, the number of peripheral blood $\mathrm{T}$ cells dramatically decreases beginning 1 month before birth and $\mathrm{B}$ cells are present in much lower numbers in developing fetuses (1-2\%) than mature calves $(10-20 \%)(15,16)$.

Dairy calves are immunologically naïve at birth, they are born agammaglobulinemic meaning they are relatively devoid of circulating antibodies (12). Indeed, neonatal calves have had no chance to enhance adaptive immunity by "experience" because of the protective environment in utero. Moreover, maternal factors at parturition, such as elevated cortisol, further depress calf immune competence. Newborn calves must obtain their antibodies from cows' colostrum via passive transfer. The immune fraction of maternal colostrum is composed primarily of antibodies but also contains cytokines, bioactive factors and cells that will activate and regulate the innate responses of calves to fight infection. Ingestion of high-quality colostrum is essential to provide neonates with immunologic protection during at least the first 2-4 weeks of life (10). It is well-recognized that a successful passive transfer of colostral immunoglobulins is crucial for calf health and survival both in the short- and long-term (17). Successful passive immunity is dependent on the content of immunoglobulin G (IgG) in the colostrum and the newborn's ability to absorb IgG (18). Colostrum-deprived calves have only trace amounts of immunoglobulins during the first 3 days of life and the risk of mortality increases significantly in the absence of passive transfer $(17,19)$. In fact, the levels of immunoglobulins (IgG, $\operatorname{IgM}$ and $\operatorname{IgA}$ ) do not approach adult levels until 4 months after birth in colostrumdeprived calves (20). In the United States, mortality rates in pre-weaned dairy heifers are estimated to range between 8 and $11 \%$, and more than $30 \%$ of this loss is attributed to failure of passive transfer (21). 


\section{FETAL PROGRAMMING AND HEAT STRESS-INDUCED ALTERATIONS IN CELL AND TISSUE FUNCTION}

The intrauterine environment experienced by the developing fetus can shape physiological responses in preparation for postnatal life. The concept of "fetal or developmental programming" is not novel. Although initially named "the Barker hypothesis," or "fetal and infant origins of adult disease," after Barker's ground-breaking studies $(22,23)$, the concept has evolved over time after a multitude of crosssectional, longitudinal, retrospective, and prospective studies were conducted in laboratory and livestock species. Fetal programming refers to suboptimal intrauterine conditions (i.e., nutritional, environmental, or social insults) during critical periods of fetal development that might lead to changes in tissue structure and/or function with long-term consequences on offspring physiology, metabolism, and disease susceptibility later in life [reviewed by (24)].

Fetal development during gestation is a result of highly organized, orchestrated changes primarily fueled by maternal nutrient supply to the fetus (25). Studies in humans, rodents, and livestock have confirmed the critical role of the placenta and the central role of epigenetic regulation of developmental programming (26). Prenatal malnutrition (i.e., over- or under-nutrition) experienced in utero is a major contributor to adverse health outcomes. Perhaps the most recognized example in livestock is the impact of intrauterine growth restriction with undernutrition on muscle development $(25,27)$. In dairy cattle, one well-recognized environmental factor that limits productivity and welfare is elevated ambient temperature and humidity $(28,29)$. Maternal exposure to high ambient temperature and humidity can create a suboptimal environment for the developing fetus. In fact, because the fetus has almost no ability to regulate its own temperature, fetal temperature is determined primarily by maternal temperature (30). It has been shown that when pregnant sheep and goats experience heat stress in late gestation, the fetus also has increased body temperature indicating a suboptimal intrauterine environment $(31,32)$. Historically, our group has focused on the prenatal exposure of the developing calf to hyperthermia during late gestation and the dramatic phenotypic alternations observed in postnatal performance [reviewed in (33)].

Potential underlying mechanisms explaining the effect of maternal hyperthermia on offspring development and health have been proposed. One limitation is the variability of "normal" body temperatures and lack of unique thresholds and dose-response relationships among different species, which preclude extrapolations. However, some general principles are conserved and responses can be inferred. For instance, the highly ordered progression of cellular processes that are critical to embryonic and fetal development (i.e., cell proliferation, migration, differentiation, and programmed cell death) are adversely susceptible to heat and therefore affected by elevated maternal temperatures (34). The existence of critical windows of developmental vulnerability of the embryo and fetus during prenatal phases applies to almost all mammalian species and refers to different stages when organs or tissues show different levels of heat sensitivity (35). For example, exposure of pre-implantation bovine embryos to hyperthermia in vitro decreases developmental competence and leads to embryonic death (36). Similar outcomes have been observed in in vivo studies with sheep, beef, and dairy cows (37-39), wherein early exposure to environmental heat stress results in decreased embryo viability and development and increased embryo loss. A retrospective study showed that periconceptional heat stress of dairy cows (conceived during summer months) was associated with differences in daughter milk production during their first lactation (40), indicating persistent effects of maternal stress insults early in fetal life. In most mammalian species, by the end of the embryonic stage, $\sim 90 \%$ of the body structures are formed, followed by the fetal stage characterized by the growth of those structures. In fact, more than $75 \%$ of calf fetal growth occurs during the last 2 months of gestation (41). Thus, maternal insults (i.e., thermal stress) that occur during this stage will likely impact the maturation and growth of tissue structures and the function of cells within tissues that may lead to increased morbidity and mortality of the offspring.

Because the bovine immune system starts developing in utero, maternal hyperthermia during pregnancy could alter the normal developmental trajectory of immune cells and organs. Literature directly linking maternal exposure to heat stress and offspring immune outcomes is scarce in the bovine model. However, "immune system programming" has been extensively documented for a variety of prenatal maternal stressors, which can lead to changes that persist over the life course of the offspring $(35,42,43)$. For example, offspring born from stressed dams have permanent alterations in their resilience to stressors and immunocompetence, primarily driven by alterations in their hypothalamic-pituitary-adrenal function (44-46). In utero hypothalamic-pituitary-adrenal axis programming also occurs in pigs (47). When in utero heat stressed pigs are exposed to postnatal stressors [i.e., handling, (48) or heat insult, (49)] they have higher cortisol concentrations and increased core temperature, respectively. It has been established that the immune system has lower priority in fetal nutrient partitioning than other systems, such as the nervous system and brain (50) which might explain the programming effect of systems regulated at the brain level (i.e., cortisol regulation and thermoregulation). Thus, hyperthermia during late gestation could be altering the nutrient partitioning to and retarding the ontogeny of the fetal immune system (i.e., the maturation and growth of lymphoid organs and immune cells). It is possible maternal hyperthermia during early stages of fetal development might impact the differentiation, migration, and/or establishment of the highly proliferative pool of lymphoid-hematopoietic progenitor cells that are destined to become immune cells; whereas hyperthermia later in development might impact growth of lymphoid organs and the cellular microenvironment impacting the development and maturation of functionally immuno-competent cells. 
Another important consideration is the duration and extent of the heat insult (i.e., acute vs. chronic exposure), which might trigger distinct mechanisms to protect the fetus from hyperthermia ranging from rapid heat shock responses to suspension of protein synthesis, cell proliferation and DNA damage in both the placenta and fetus. Some of these responses seem to be conserved across mammals (34). In general, acute stressors enhance innate immunity and drive cytokine secretion, whereas chronic stress favors inflammation (43). Notably, not all fetal programming should be seen with negative connotations; in fact, resultant changes in organ structure, function, and gene expression might serve to enable the developing fetus to adapt to the environment postnatally. Understanding the programming mechanisms and implications of pre- (in utero) and postnatal (ex utero) exposure to thermal stress is critical for the development and implementation of meaningful management practices and mitigation strategies to improve productivity, health and wellbeing of dairy calves.

\section{EFFECTS OF HEAT STRESS DURING THE PRENATAL PERIOD ON IMMUNITY}

Exposure to prenatal maternal stressors during fetal development have lifelong consequences that impede the expression of the genetic potential of the offspring. Past and ongoing studies in our laboratory have revealed a series of immune alterations in the bovine calf immune response during early life and preweaning period that result from exposure to in utero heat stress during a relatively brief period of late gestation (i.e., the dry period of the dam).

Prenatal heat stress impairs passive transfer of colostral IgG. Newborn calves born to heat stressed dams and fed colostrum from their respective mothers have reduced apparent efficiency of IgG absorption, compared with calves born to cooled dams and receiving their dam's colostrum (51, 52). Whereas, the reduced quality of colostrum collected during summer compared with colostrum collected during other seasons has been reported, the impact of late-gestation heat stress on colostrum IgG concentration has been inconsistent in controlled studies. Some studies have reported decreased $\operatorname{IgG}(53,54)$, others have observed no differences in $\operatorname{IgG}(51,55)$ or even increased concentrations of $\operatorname{IgG}$ (56) in the colostrum of heat stressed dams. Regardless of these conflicting results, Monteiro et al. (55) demonstrated that prenatal heat stress alters the calf's capacity for IgG transfer rather than reducing the quality of the colostrum produced by the dam. Later work from our laboratory indicated that calves exposed to in utero heat stress have more apoptotic enterocytes in the jejunum at birth relative to calves born to cooled dams (57). In goat kids, Castro-Alonso et al. (58) provided evidence that the process of gut closure is mediated by apoptosis of enterocytes, so the acceleration of this process in heat stressed calves suggests a decrease in the capacity for postnatal Ig absorption of colostral antibodies. Heat stress exposure can compromise intestinal integrity in cows, pigs, and humans (5961 ), however whether maternal heat stress causes impairment of epithelial gut function of the offspring beyond the first days of life has yet to be determined.

Prenatal heat stress reduces the overall immune competence of calves during their postnatal life by derailing hematological parameters and cellular immune status from normal. For example, calves born to heat stressed dams, receiving colostrum from their dams, had reduced circulating plasma proteins (51), red blood cell counts, platelets and circulating hemoglobin, lower lymphocyte counts, and increased circulating concentration of acute phase proteins during the pre-weaning period relative to those born to cooled dams receiving colostrum from their dams (56). Peripheral blood mononuclear cells (PBMC) were isolated from in utero heat stressed or cooled calves' blood during the pre-weaning stage and were incubated in vitro with a mitogen. A significant reduction in proliferation rate was observed in in utero heat stressed calves compared with in utero cooled calves $(51,55)$. Acute maternal heat stress exposure can impact the cellular immune status of the pre-weaned calf. For instance, maternal heat stress during late gestation inhibits the immune response of the offspring, by modifying $\mathrm{T}$ and $\mathrm{B}$ cell function (35). Strong et al. (62) reported a reduction in lymphocyte percentage and downregulation of blood immune markers (i.e., TNF $\alpha$ and toll-like receptor 2) in the first several weeks after birth of calves born to dams exposed to acute heat stress during late gestation.

Alteration of tissue morphology and function is one of the primary processes whereby developmental insults, such as hyperthermia, might exert permanent effects later in life (63). A hallmark of late gestation heat stress in the developing calf is the reduction in birth weight $(51,64-66)$. Intrauterine growth retardation might result from reduced uterine blood flow and nutrient availability to the placenta. Recent data from our group indicates that the placenta of heat stressed dams possess cotyledons with increased surface area, perhaps to increase the surface area for oxygen and nutrient exchange, but more likely as a mechanism to remove heat as they typically have no structural association with the fetus (67). Compromised placental vascularization is also observed in sheep, which might indicate less efficient oxygen diffusion to the growing fetus (68). A significant reduction in birth weight of in utero heat stressed calves was accompanied by reduction in immune organs (i.e., the thymus and spleen) relative to in utero cooled calves (57). Maturation of T cells, which are responsible for mounting an immune response to foreign substances, takes place in the thymus, while the spleen filters the blood and stores platelets and white blood cells. Abnormal development of these lymphoid organs can have severe consequences for an animals' adaptive immune function and ultimately compromise their health and survival. It is possible that immune outcomes are the first to be impacted under a moderate intrauterine hyperthermia and that only a more severe stress would impact other tissues and organs (i.e., liver and muscle) to influence overall birth bodyweight reductions. This hypothesis is supported by observations in severely heat stressed intrauterine growth restricted ewes that exhibit alterations in the brain and metabolic tissues resulting in a shift of fetal metabolism from anabolic to catabolic pathways (69). In addition, in utero heat stress also reduced the size of the liver of neonatal dairy calves (57). Even though the liver is 
considered a metabolic organ, it can also serve as an immune organ. In fact, in utero heat stress altered the hepatic methylation pattern of genes involved in immune pathways in hepatic tissue; including the major histocompatibility complex and interlukin-8 (70). The impact of intrauterine growth restriction on immunity has been reported in several other species as well. In humans, it diminishes platelets, white blood cell and neutrophil counts and the secretion of various interleukins resulting in higher risk of mortality (71). Intrauterine growth restricted piglets have decreased relative weights of the thymus, spleen, mesenteric lymph node, and reduced levels of circulating cytokines (72) and reduced total number of CD4+ and CD8+ T lymphocytes in the thymus (73).

Compromised passive transfer of immunity coupled with under-developed immune organs might impact health and reduce survival during the postnatal period. This premise is supported by recent reports from our group showing that a higher percentage of heifers that were exposed to in utero hyperthermia leave the herd before they reach their first lactation, compared to those that were gestated under thermoneutral intrauterine environments $(74,75)$. The underlying mechanisms whereby hyperthermia drives these changes in utero and the mechanisms resulting in compromised immune function postnatally remain to be elucidated in the bovine model. Nevertheless, epigenetic regulation, e.g., gene silencing via DNA methylation and/or histone modifications, has been proposed as one process by which environmental factors could induce long-lasting regulation of gene expression in immune cells (76).

\section{EFFECTS OF HEAT STRESS DURING THE POSTNATAL PERIOD ON IMMUNITY-PREWEANED CALVES}

Although significant attention has been focused on understanding the direct impact of heat stress on lactating and more recently of dry cows [reviewed by (28) and (33)], and the development of strategies to alleviate it; pre-weaned calves are often not considered when implementing heat stress abatement. The notion that calves are less susceptible to heat stress, coupled with the lack of immediate milk production losses, might have driven the perception that cooling calves is not economically beneficial in the short-term. Consequently, study of the effects of heat stress on immune function of the neonatal calf has been less well-documented. Like mature cows, when calves exceed their ability to dissipate heat and maintain homeostasis, physiological heat stress occurs, however; the thermal neutral zone for young calves is narrower. Calves under 3 weeks of age have a thermal neutral zone between $15-25.6^{\circ} \mathrm{C}$, whereas calves older than 3 weeks begin to experience heat stress at $20-21^{\circ} \mathrm{C}(77)$. Above these temperatures, the calf will shift energy from growth to maintain body temperature. Physiological and behavioral impairments (i.e., reduced feed intakes, increased maintenance energy needs, and lowered immunity) can lead to poor growth, higher susceptibility to disease, and in extreme cases, death. Indeed, Zhai et al. (78) found that heat stress increased autophagy in the rumen, duodenum, and kidney of bull calves at 35 days of age, suggesting that nutrient uptake capacity may be altered. Yet, temperature thresholds might vary depending on size, breed, nutrition, behavior, bedding, precipitation and humidity levels, among others [reviewed by (79)]. For instance, calves exposed to increasing temperature for $7 \mathrm{~h}$, did not show signs of heat stress until temperatures approached $32^{\circ} \mathrm{C}$ with $60 \%$ relative humidity (80). In California, average daily temperatures above $25^{\circ} \mathrm{C}$ were associated with higher calf mortality (81). In addition to higher mortality rates, Heinrichs et al. (82) reported an association between calf heat stress and subsequent performance, where the higher temperatures and humidity experienced by calves resulted in higher heifer age at first calving.

The immune system of the dairy calf is compromised by direct exposure to heat stress. However, limited studies evaluate the direct impact of heat stress or heat abatement on calf immune status, and those studies vary greatly in the duration of the heat insult, the age of the animal and limited to environmentally controlled chambers. For instance, young dairy calves exposed to constant high heat $\left(35^{\circ} \mathrm{C}\right)$ conditions showed impaired antibody- and cell-mediated immunity relative to those under thermoneutral $\left(22.8^{\circ} \mathrm{C}\right)$ conditions (83). More specifically, after heat exposure for 3 to 14 days, circulating IgG was reduced by $27 \%$ and the number of peripheral blood lymphocytes was reduced compared with calves that were held at thermoneutrality. Acute heat stress (i.e., $37^{\circ} \mathrm{C}$ and $90 \%$ humidity for $12 \mathrm{~h}$ ) exposure of post-weaned dairy calves triggers the expression of genes involved in immune responses and immunity-related signaling pathways (84). Several immune-related pathways, such as Tolllike receptor, T- and B-cell receptor signaling pathways, as well as antigen processing and presentation pathways were upregulated in the blood in response to acute heat stress. Pigs exposed to chronic heat stress $\left(30^{\circ} \mathrm{C}\right)$ for 3 weeks during the finishing phase have reduced liver size and the hepatic protein signature indicate an induction of an innate immune response compared with thermoneutral pigs $\left(21.7^{\circ} \mathrm{C}\right)$. These hepatic responses were observed only in heat-stressed pigs independent of reduced feed intake (85). Postnatal exposure of pigs to heat or thermoneutral conditions $\left(32.8\right.$ vs. $\left.23.9^{\circ} \mathrm{C}\right)$ resulted in increased neutrophil numbers and decreased antibody production (86).

\section{EFFECTS OF HEAT STRESS DURING THE POSTNATAL PERIOD ON IMMUNITY-GROWING HEIFERS}

The effects of heat stress on immunity in the growing heifer (i.e., post-weaning) has not been studied extensively, potentially due to a combination of the lower disease incidence of this group of animals, the notion that heifers are less impacted by heat stress compared with lactating cows, and the fact that the economic return to manage heat stress for growing heifers is not immediately evident. In a recent survey conducted in the western and eastern regions of the US (87), 5.1 and $1.0 \%$ of weaned heifers (from weaning to calving) were affected by respiratory and digestive diseases (including diarrhea), respectively, rates that are much lower relative to pre-weaned calves (12.0 and 21.1\% 
incidences for respiratory and digestive diseases, respectively). Calving season may influence the mortality and morbidity of growing heifers. In a study conducted in small size dairy herds $(<100$ cows/herd) in southwest Sweden, heifers born during summer (May to August) had lower risk of mortality or improved survival from calving to 810 days of age compared with heifers calved during winter (December to April) (88). A study conducted in Ontario, Canada and Minnesota, USA, reported that heifers born during winter (December to February) had greater risk of bovine respiratory disease from 5 week to 3 months of age relative to those born during summer (June to August) (89). The impact of calving season is difficult to interpret because heifers born in one season could be at risk of getting a disease in another season, and therefore they are confounded with time.

However, the potential impact of heat stress on growing heifers should not be ignored. When exposed to elevated ambient temperature from 10 to $35^{\circ} \mathrm{C}$, yearling heifers exhibit increased rectal temperature (RT), respiration rate (RR), and pulmonary ventilation rate (volume of exhaled air per min) but decreased tidal air (volume of exhaled air per respiration) (90). Those symptoms are similar to a mature heat-stressed cow and suggest that heifers also suffer from hyperthermia. The body surface area of the growing heifers increases from 1 to 12 months of age; however, the ratio of body surface area to bodyweight decreases and the heat production per unit of body surface area gradually increases as heifers grow $(91,92)$. These observations suggest that dissipation of metabolic heat gradually decreases and heat tolerance of the animal decreases as heifers develop. On the other hand, because heat dissipation through radiation, convection, conduction and evaporation is positively dependent on body surface area (2), the increased body surface area of growing heifers from 1 to 12 months of age also suggests increased ability to dissipate heat through sensible and latent heat loss, especially under cooling in field conditions.

Heat stress may directly impair the immunity of heifers, but reported results vary. In PBMC isolated from beef heifers of three cattle breeds, exposure to $42^{\circ} \mathrm{C}$ for $12 \mathrm{~h}$ reduces cell viability and $\left[{ }^{3} \mathrm{H}\right]$-thymidine incorporation into newly synthesized DNA compared with those incubated at $38.5^{\circ} \mathrm{C}$, suggesting reduced cell survival and PBMC proliferation under heat shock in vitro (93). Further, cells collected from Angus heifers (heat sensitive Bos Taurus) had greater rate of cell death when exposed to in vitro heat shock $\left(42\right.$ or $\left.45^{\circ} \mathrm{C}\right)$ relative to those collected from Brahman (heat tolerant Bos Indicus) and Senepol heifers (heat tolerant Bos Taurus), indicating a breed difference in cellular responses to heat shock in vitro (93). Carroll et al. (94) reported that, after an intravenous endotoxin challenge, Angus heifers ( $\sim 19$ months of age) exposed to heat stress conditions had greater TNF $\alpha$ release but lower blood INF $\gamma$ concentrations compared with heifers under thermoneutrality, while heat-stressed Romosinuano (heat tolerant Bos taurus) heifers had lower blood TNF $\alpha$ concentration but greater INF $\gamma$ concentration relative to thermoneutral heifers. These results further indicate a genetic impact on animal's immune responses to heat stress.

Heat stress may also disrupt the redox status of beef heifers, thereby increasing exposure to lipid hydroperoxides and other byproducts of oxidation that could harm immune cells. In
Angus heifers $(\mathrm{BW}=329 \pm 14 \mathrm{~kg})$ grazing tall fescue during summer, PBMC collected during hotter days in July and August had a lower ratio of reduced to oxidized glutathione, lower glutathione reductase activity but a lower glutathione peroxidase activity compared with those collected during cooler days in June, suggesting that elevated ambient temperature alters oxidative balance of immune cells (95). However, these data are confounded with the decline in forage availability and quality during the summer that also influences the oxidative redox state of immune cells (95). In beef heifers (Angus-crossbred and Charolais-crossbred, initial BW $=355 \mathrm{~kg}$ ), providing shade in the feedlot decreases the percentage of neutrophils and increases the percentage of lymphocytes in the white blood cell population, but did not influence neutrophil chemotaxis (96). Thus, the effects of heat stress on immune function may be exacerbated by other nutritional and management interventions.

In dairy breeds, exposure of blood polymorphonuclear leukocytes isolated from Holstein heifers (310-322 days of age) growing under thermoneutral or $42^{\circ} \mathrm{C}$ in vitro reduces oxidative burst capacity as measured by cytochrome $\mathrm{c}$ reduction, the ability of cells to phagocytize and kill E. coli, and random cell migration, compared with those exposed to $38.5^{\circ} \mathrm{C}$ (97). Lymphocytes isolated from the same group of animals had decreased proliferative responses with or without mitogen stimulation when exposed to $42^{\circ} \mathrm{C}$ relative to $38.5^{\circ} \mathrm{C}$ in vitro (97). These data suggest that the function of cells of both the innate and adaptive arms of the immune system of Holstein heifers are compromised by elevated ambient temperature in vitro. Controlled studies that examine the impact of heat stress on immune cell function growing dairy heifers are rare. However, in a preliminary study (Bubolz, Tao and Dahl, unpublished, University of Florida), Holstein heifers $(n=8,98 \pm 14$ days of age, $\mathrm{BW}=128 \pm 15 \mathrm{~kg}$ ) were balanced by age and BW and randomly assigned to two environmental chambers provided with either a constant heat stress $(\mathrm{THI}=79-82)$ or thermoneutral conditions (THI $=61-64)$. A crossover design was utilized in this experiment. Heifers were maintained on their initial treatment for 3 weeks and then switched to the opposite thermal regimen for the other 3 weeks. There was a 2 week washout period between treatment periods when thermoneutral conditions were maintained in both chambers. Peripheral blood mononuclear cells were isolated from all animals and their proliferative responses to concanavalin $\mathrm{A}$ were evaluated using ${ }^{3}[\mathrm{H}]$-thymidine incorporation. Neutrophil function assays including phagocytosis and oxidative burst were performed as well. During heat stress, heifers had greater $(P \leq 0.001)$ body surface temperature in the morning (35.0 vs. $\left.30.6^{\circ} \mathrm{C}\right)$ and afternoon $\left(36.8\right.$ vs. $\left.31.6^{\circ} \mathrm{C}\right)$, reduced $(P<$ $0.001)$ dry matter intake as a percentage of BW (2.29 vs. $3.83 \%)$, and increased $(P<0.04)$ water consumption $(29.2$ vs. $18.0 \mathrm{~L} / \mathrm{d}$ ) relative to thermoneutral heifers, confirming the effectiveness of the treatments. However, compared with thermoneutral heifers, heat-stressed heifers had similar $(P>$ 0.60) PBMC proliferation (15136 vs. 15488 DPM, respectively), and neutrophil phagocytosis (52.7 vs. $51.2 \%$, respectively) and oxidative burst (59.1 vs. $61.4 \%$, respectively). These data suggest that exposure to a heat stress environment may not have a 
significant impact on the white blood cell functions of growing dairy heifers.

Despite the lack of conclusive evidence for heat stress to affect immune function in growing heifers, the impact may vary depending on genetic background and physiological stage of the animals, degree of heat stress, the housing facility etc. Indeed, in addition to the potential and direct impact of heat stress on heifers' immunity, one cannot ignore the importance of surround environment of animals during summer on the risk of developing a disease. For example, fly control is a critical management strategy to reduce the incidence of heifer mastitis, especially during summer (98). Dairy herds that adopt fly control programs have lower incidence of heifer mastitis compared with those without fly control (98). Heat stress may therefore act in combination to alter disease effects even in the absence of a direct input to immune function in growing dairy heifers.

\section{EFFECTS OF HEAT STRESS DURING THE POSTNATAL PERIOD ON IMMUNITY-LACTATING COWS}

Mastitis and metritis represent two of the primary pathogens induced diseases of cattle during lactation, and there is evidence that heat stress exacerbates the occurrence of both diseases. Milk somatic cell content (SCC] is an indicator of subclinical mastitis and elevations are associated with reductions in yield and processing quality (99). Using milk quality measures as a proxy for immune status, especially SCC or SC score (SCS), a number of studies support the concept that heat stress increases immune responses when compared with cooler ambient temperatures. In temperate $(100,101)$ and subtropical $(102)$ environments, elevations in THI during summer months was associated with higher SCC at the herd level, and there were concomitant decreases in milk volume and quality. Whereas, overall pathogen load would be expected to increase with higher temperatures, seasonal differences exist with specific pathogens that are inconsistent with higher mastitis incidence resulting only from higher pathogen exposure. For example, Lundberg et al. (103) that in one herd monitored for 16 months, S. dysgalactiae infections were highest at the end of the summer pasture season (i.e., after heat stress) whereas S. uberis infections were greatest during the winter when cows were housed indoors. Therefore, it is likely that direct impacts of heat stress on host immune function plays a role in the cow's ability to resist infection. Indeed, recent study with limited heat stress abatement in early lactation cows shows improvements in immune status with cooling (104). In an arid environment with mean daily temperatures of $37^{\circ} \mathrm{C}$, exposure to fans and misters from 1000 to $1800 \mathrm{~h}$ each day improved milk yield and dry matter intake relative to cows that received not heat abatement. Heat stress increased SCC in milk, but depressed circulating IgG and inflammatory cytokines, supporting the idea that cow immune function is adversely affected by heat stress during lactation.

A linkage of uterine disease with heat stress has been observed for decades. DuBois and Williams (105) examined seasonal incidence of retained placenta in a single herd, and found that the percentage of cows with a retained placenta (RP) doubled in the summer relative to the winter, and cows with an RP had an additional 24 days open compared with the reproductive performance of healthy cows. A recent study by Gernand et al. (106) tied the relationship of RP and metritis more closely to increases in THI. With records from 22,000 cows, puerperal disorders and RP increased linearly with the average THI in the 5 days after calving. Of interest, there was no association of the THI in the previous week on RP and metritis, suggesting that there is a period early postpartum when cows are acutely sensitive to heat stress from an immune perspective. More recent data collected from cows presenting with metritis indicates higher incidence in summer regardless of bacterial load, and greater persistency of the negative impacts of metritis on performance when it occurs in the summer vs. the winter months $(107,108)$. Collectively, the evidence indicates that as temperature and humidity rise, there are effects on host response to pathogens that are associated with elevated incidence of disease.

Direct evidence of heat stress effects on immune cell function in mature cows has been obtained using in vitro culture with direct intervention after collection of samples. Lacetera et al. (109) attempted to mimic a natural exposure of heat stress insults in PBMC collected from Holstein and Brown Swiss cows. Over $65 \mathrm{~h}$ in culture, PBMC were exposed to cycles through $39^{\circ} \mathrm{C}$ and $42^{\circ} \mathrm{C}$ at $13 \mathrm{~h}$ intervals. Expression of heat shock protein 72 (HSP72) increased with temperature, and a concomitant reduction in PBMC DNA synthesis was observed with heat stress relative to normothermia. Thus, PBMC react to temperature directly with a loss of function consistent with a reduction in immune function in vivo. Of interest, Holstein cows were impacted significantly less than Brown Swiss, which indicates some genetic variability in resilience to heat stress. Lecchi et al. (110) assessed the effect of in vitro heat stress on actual polymorphonuclear cells ability to phagocytize and generate oxidative burst activity. As heat increased in culture using a similar $39-42^{\circ} \mathrm{C}$ increment as previous studies, the phagocytic and burst capacity of the cells declined, evidence of a functional decline in immune system resilience with heat stress. Therefore, various immune cells suffer direct effects of heat stress on functionality, and that is likely responsible for the observed impacts on disease incidence with heat stress.

\section{EFFECTS OF HEAT STRESS DURING THE POSTNATAL PERIOD ON IMMUNITY-DRY Cows}

The dry period, or the non-lactating interval between successive lactations, coincides with a period of elevated pathogenic and metabolic disease incidence in cattle (111). Particularly in dairy cattle, new intra-mammary infections peak around dry off and calving relative to all other phases of lactation (112). The incidence rates vary with season but are typically elevated in the summer season in comparison with winter (113). Whereas, the potential for greater pathogen loading is certainly enhanced with the warmer ambient temperatures of summer, there is substantial evidence that those same temperatures have a negative impact on 
the cow's immune function as well. Therefore, both exposure and response capacity are negatively impacted by heat stress.

Lacetera et al. (114) reported that moderate heat stress that increased RT and RR did not affect indicators of cell-mediated immunity. The model was a comparison of cows calving in the spring vs. summer, and thus the in this model there is confounding of heat exposure with time. Studies designed to directly compare heat stress and cooling reveal differences in immune response. Regarding the adaptive arm of the immune system, lymphocyte proliferation represents the "gold standard" in vitro assay of activity, and heat stressed dry cows have depressed lymphocyte proliferation relative to cooled cows (115). Heat stress decreases expression of prolactin (PRL) receptor (PRL-R) mRNA, and increases circulating PRL, suggesting that PRL signaling affects lymphocyte function directly. In vivo, heat stress depresses responses to antigens, which may have implications for vaccination protocols used during the dry period to prepare cows for the next lactation (116). In that study cows were immunized with chicken ovalbumin on the day of dry off, and then boosted at $14 \mathrm{~d}$ intervals through early lactation. Responses to each successive boost were muted in the cows during heat stress exposure in the dry period, but differences in antigen response disappeared after calving.

Evidence of direct effects of heat stress on innate immune function in the dry period is lacking, but carry-over effects, similar to those observed with lymphocyte gene expression (115), do occur. Specifically, neutrophil phagocytosis and oxidative burst activity is enhanced in cows that are cooled when dry relative to those that were under heat stress, even though all cows were cooled during lactation (116). Further, this effect alters the response to a post-partum pathogen challenge. Following treatment by cooling or heat stress in the dry period, Thompson et al. (117) observed an increase in circulating neutrophils with dry period cooling compared with heat stress. Toll-like receptor2 (TLR-2) expression in white blood cells was greater with cooling relative to heat stress, indicating that the pro-inflammatory activity of those cells was higher given the action of TLR-2 is associated with pathogen recognition. After infusing S. uberis into the mammary gland, greater TLR-2 expression persisted in cooled cows, whereas heat stress increased expression of interleukin-10, which indicates more robust down regulation of the pro-inflammatory response. Thus, heat stress depresses the cow's ability to mount responses to pathogens at the cellular level.

Recent studies that examined the impact of dry period season, i.e., summer vs. winter, as a proxy for heat stress effects reveal effects on disease incidence consistent with the observed impacts on immune function. Thompson and Dahl (118) compared disease incidence with season of dry period in cows housed outdoors in Florida, and observed that dry periods corresponding to the summer months increased the incidence of mastitis, respiratory disease and displaced abomasum, suggesting that high ambient temperatures in summer reduced the immune competence of cows. Collectively, these data support the idea that heat stress in the dry period has direct and indirect suppressive impacts on immune function in the cow, which result in greater disease incidence and reduced performance.

\section{MANAGEMENT INTERVENTIONS}

Beede and Collier (119) proposed three approaches to alleviate the impact of heat stress: (1) modification of the environment, (2) genetic selection for heat tolerant cows, and (3) nutritional management. Because genetically altering the thermal tolerance of high producing animals is difficult (120), and there are many reviews that cover nutritional and metabolic responses and nutritional management for heat-stressed dairy cattle [i.e., $(119,121)]$, this section will briefly review heat abatement by physical modification of the environment. A recent analysis predicts that the milk production loss due to heat stress increases at a rate of $174 \pm 7 \mathrm{~kg} / \mathrm{cow} /$ decade in the $21 \mathrm{st}$ century, but implementation of intensive cooling using fans, water or air conditioning minimizes the loss of milk yield and is associated with significant economic return for dairy producers (122). Therefore, heat abatement is an efficient and profitable approach to alleviate the negative impacts of heat stress and is the essential component of heat stress management on dairy farms.

Heat stress abatement begins with effective determination of the heat load cows are exposed to. Temperature-humidity index is the most common measure of heat stress in the dairy industry (123). It combines the impacts of dry bulb temperature and relative humidity but does not include solar radiation and wind speed. Therefore, THI may be a good indicator of heat stress in housing structures but may not be suitable for open lot or pasture-based facilities where a black globe humidity index has been developed to incorporate the effects of solar radiation (124). Zimbleman et al. (125) reported that, when daily average THI exceeds 68 , the milk yield of the high producing dairy cow starts to decrease. The THI above which the immune function of dairy cattle is influenced has not been identified. Because heat stress is defined as imbalanced thermal relation between an organism and its environment that induces hyperthermia (126), any heat abatement that reduces hyperthermia should not only improve the production performance (i.e., milk yield and growth), but also help maintain optimal immune function of dairy cattle under heat stress condition.

Providing shade effectively blocks solar radiation $(127,128)$, and should be utilized as the first step in heat abatement. Under moderate heat stress in a temperate climate, grazing cows exposed to shade have no differences (129) or slight decreases in body temperature during the hottest time of the day (130) relative to non-shaded cows. Consequently, cows provided with shade have similar (129) or small increases in milk yield [ $3 \%$, $(130,131)]$ compared with non-shaded cows. In contrast, in the subtropical climate of Florida, cooling with access to shade alone dramatically decreases body temperature and respiration rate of lactating dairy cows and improves milk yield by $11-20 \%$ $(127,128)$. A mature dairy cow requires 3.5 to $4.5 \mathrm{~m}^{2}$ of space under shade, and the shade should be $3.5-4.5 \mathrm{~m}$ high to minimize the radiation from shade roof to cows (123).

Besides shade, additional evaporative cooling can be implemented to further abate heat stress. Depending on the climate, evaporative cooling can be accomplished by either cooling the air or increasing the evaporative heat loss on the body surface of animals. In a dry and arid climate, evaporative 
cooling can be achieved through the generation of very fine water droplets that are suspended in the air and evaporate. This reduces the air temperature around cows, which improves sensible heat loss; however, the effectiveness is reduced as relative humidity increases (123). In both dry and humid climates, the combination of soakers (usually over the feedline) and fans are effective for cooling cows. Soakers or sprinklers typically deliver large water droplets through a low-pressure water line to wet the skin and hair coat of cows. The airflow provided by fans facilitates the evaporation of water from the skin, which carries heat directly away from the cows' body (132). Heat abatement using this type of active cooling system reduces the body temperature and respiration rate, increases production performance, and improves the immune function of heat-stressed cows $(115,116,133)$. Alternatively, the feedline soakers may be replaced by high pressure misters or foggers placed on the face of fans. A study conducted in Kansas suggests that misters and fans reduce lactating cows' body temperature to a similar extent compared with soakers and fans (soakers operating cycle: $1 \mathrm{~min}$ on and $4 \mathrm{~min}$ off) (134). In a 3 months study conducted in southern Georgia, Weng et al. (135) reported that the daily average vaginal temperature of lactating cows cooled by misters and fans over the feedline and stalls was $0.9^{\circ} \mathrm{C}$ lower (39.0 vs. $39.9^{\circ} \mathrm{C}$, respectively) than those without cooling in a free stall barn.

Air movement is critical for heat abatement. In naturally ventilated barns, additional fans increase ventilation and air velocity, which enhances heat loss by convection (when air temperature is lower than cow surface temperature) and evaporation (2). Low volume, high-speed fans are effective to reduce cow body temperature when combined with soakers or misters. Brouk et al. (136) reported that air velocity provided by fans equal to or above $8 \mathrm{~km} / \mathrm{h}$ at the cow level was necessary to maximize the reduction in cow body temperature when soakers are on a $1 \mathrm{~min}$ on and $4 \mathrm{~min}$ off cycle. In addition to the feedline cooling systems, fans over the freestalls are reported to further reduce respiration rate, increase intake and milk yield, and enhance lying time in stalls of lactating dairy cows $(137,138)$.

Compared with confinement dairies, optimal cooling strategies for grazing cattle have not been identified. As described above, providing shade is an effective approach to block solar radiation for cooling grazing dairy cattle. In some areas of the US, cows on pasture are cooled by sprinklers or misters installed on an irrigation pivot. This system is effective to reduce cow body temperature to a certain extent, but the degree of cooling is also dependent on other factors such as wind speed, relative humidity, the types of nozzles on pivots, the distance between nozzles, pressure of water, etc. Additionally, evaporative cooling using sprinklers and fans, or misters, in the holding area before milking effectively reduces cow body temperature after milking, and results in $4-5 \%$ increase in milk yield of lactating dairy cows in grazing based dairies (139-141). In some dairies, cows are often fed a partial total mixed ration in feedlots before or after milking, and appropriately designed cooling systems in the feeding area will help maintain the body temperature of cows before returning to the pasture.
Cooling dry cows should be emphasized in the heat stress management of a dairy farm because of the significant benefits on production and health of cows and calves. The more effective the cooling approach applied to dry cows, the greater the reduction in heat strain observed in cows. One early study (64) reported that providing shade to late gestation cows on pasture decreased cow body temperature (39.2 vs. $40.0^{\circ} \mathrm{C}$, respectively) and respiration rate (63.3 vs. 87.4 breaths/min, respectively) compared with those without shade. A recent study (142) compared different heat abatement strategies on body temperature and respiration rate of close-up dry cows, and found that cows housed in a free stall barn cooled by feedline soakers and fans had lower average daily vaginal temperature (38.9 vs. $39.1^{\circ} \mathrm{C}$, respectively) and respiration rate (43 vs. 69 breaths/min, respectively) relative to those housed on pasture with shade. Cooling during the entire dry period improves milk yield in the subsequent lactation by 4 to $5 \mathrm{~kg} / \mathrm{d}(65,116,143)$. The length of cooling during the dry period also determines the production response of cows. Fabris et al. (66) reported that depriving dry cows of evaporative cooling (i.e., feedline soakers and fans over the free stall) during the first half, the second half, or the entire dry period equally reduced the subsequent milk yield compared with those cooled during the entire dry period. Thus, to achieve the full benefit of dry cow cooling, cows need to receive maximal cooling during both far-off and close-up periods.

Historically, the development of preventative management strategies to alleviate heat stress in calves has focused on individually housed calves (i.e., outdoor pen or hutches), where additional abatement strategies, beyond shade or different hutch materials, cannot be easily implemented. A survey conducted in the western and eastern regions of the US summarized 11 housing types for preweaned calves (87). Among the dairy operations surveyed, $37.9 \%$ used individual outside hutches and $31.8 \%$ adopted individual inside hutch/pen (87), whereas in Canada $88 \%$ of calves are housed in hutches (79). The construction materials of outside hutches influence the heat load carried by calves and that potentially affects their growth and health. For instance, plastic hutches tended to average $3-6^{\circ} \mathrm{C}$ higher than wooden hutches (144). Relative to hutches made of plywood, polyethylene hutches maintain greater internal air temperatures at the hottest times of a day and increase calves' respiration rate and skin and rectal temperatures in the afternoon (145). Peña et al. (146) compared polyethylene hutches with wire hutches covered by a plywood roof in the subtropical climate of Florida and reported that calves raised in polyethylene hutches had increased respiration rates and rectal temperatures in the afternoon compared with those in the wire hutches with plywood covers. Both groups of calves had similar growth during the preweaning period, but calves raised in the wire hutches showed greater incidence of respiratory diseases, as indicated by nasal discharge and coughing, and required more veterinary treatments relative to those raised in polyethylene hutches (146).

Regardless of hutch material, temperatures above $29^{\circ} \mathrm{C}$ inside the hutches have been reported (147). Even in moderate U.S climates, the average hutch interior can reach $22.8^{\circ} \mathrm{C}$ and a THI of 68 in summer, indicating severe heat stress (148). A study in Arizona reported the highest THI, highest cortisol 
levels, lower circulating IgG, and higher incidence of mortality in calves housed in portable-solid wall hutches, compared to improved housing systems by provision of shade and pre-cooled air (149). Two studies in the southeastern region of U.S. provided supplemental shade ( $80 \%$ shade cloth above the hutch) to calves housed in polyethylene hutches reporting reductions in interior temperature of the hutch, compared with hutches under direct sunlight, which translated into reductions in respiration rates (150) and better feed-to-gain ratio (151). Average elevation in respiration rates and heart rates of 20 beats/min and rectal and skin temperatures of 0.5 and $1.6^{\circ} \mathrm{C}$ have been observed when comparing un-shaded 7 days old bull calves with those provided with shade during a 3 days heat event (152).

Ventilation is important not only to facilitate heat abatement of calves but also minimize the occurrence of respiratory disease. In a relatively dry environment (relative humidity ranges from 15 to $70 \%$ ), elevating the back of polyethylene hutches by $20 \mathrm{~cm}$ slightly reduces the internal ambient temperature of hutches by $0.12^{\circ} \mathrm{C}$ compared with the external ambient temperature and decreases the respiration rate of calves in the afternoon (153). Importantly, hutch elevation results in lower concentrations of airborne bacteria and decreases carbon dioxide levels in hutches, suggesting improved air quality (153). In a study conducted in Ohio in the summer (air temperature: max: $37^{\circ} \mathrm{C}$, min: $9^{\circ} \mathrm{C}$ ), calves were housed in wire panel hutches in a barn and cooled by fans or not from 0800 to $1700 \mathrm{~h}$, to examine if forced ventilation improves calf performance (154). Compared with non-cooled calves, cooled calves had lower respiration rates and increased average daily gain and feed efficiency, suggesting that the reduced heat load improved their performance (154). But in the enclosed environment of an individual polyethylene hutch, cooling by fans may not be effective. Additionally, because convective heat loss is temperature dependent, the effectiveness of forced ventilation for cooling will be minimized when air temperature exceeds the calves' body surface temperature. Water for heat abatement (i.e., soaking or evaporative cooling) for dairy calves needs to be viewed with caution as excessive water may wet bedding material, which poses a risk for greater bacterial growth and disease development. Nevertheless, a dry and clean environment and good ventilation are basic requirements for any calf housing.

The use of automatic feeders coupled with the increased popularity of group-housing has allowed the possibility of implementing active cooling strategies to provide heat abatement more efficiently to calves. For example, increasing the area for shade (i.e., solid roof) and airflow and the option to add ventilation systems, such as natural ventilation (i.e., curtains and open walls), fans, or positive-pressure tubing are all possible with group housing but not in hutches. To date, limited research has reported benefits of cooling systems in group housed dairy calves and controlled studies describing the direct impact of heat stress exposure on immune parameters of pre-weaned group dairy calves are lacking. Emerging data from our group suggests that providing heat stress abatement to pre-weaned calves, using fans at calf-level with an average wind speed of $3.0 \mathrm{~m} / \mathrm{s}$, might positively impact their thermoregulatory ability and increase circulating levels of immune cells. Dairy calves experiencing heat stress postnatally have increased body and skin temperatures $\left(+0.7^{\circ} \mathrm{C}\right.$ and $+1.7^{\circ} \mathrm{C}$, respectively) coupled with depressed feed intakes which led to reduced average daily gains compared with calves with access to fans (155). Postnatal cooling improved calves' red blood cell counts and increased the percentage of circulating neutrophils relative to heat stressed calves (Laporta, unpublished data). Functional assays and quantification of specific immune cells are underway to assess whether postnatally cooling might improve immune response to vaccinations. However, even though the heat abatement applied was successful in cooling the calves postnatally, our preliminary observations indicate that it might not be enough to overcome the impact that prenatal (in utero) heat stress exerts on, for example, growth parameters (155).

As mentioned previously, heat abatement for growing heifers has not been studied extensively, perhaps due to the perception of low economic returns on any investment in cooling facilities. In beef heifers (Angus-crossbred and Charolais-crossbred, initial $\mathrm{BW}=355 \mathrm{~kg}$ ), shade structures (galvanized steel-roofed shade) reduced respiration rates of heifers, and increased feed intake and average daily gain compared with un-shaded animals during summer in Texas (96). In a study conducted in environmental chambers (air temperature $=26.1-37.8^{\circ} \mathrm{C}$; THI $=76-88$ ) using Shorthorn heifers $(\mathrm{BW}=369 \mathrm{~kg}$ ), continuous sprinkling on heat-stressed heifers from $1200-1600 \mathrm{~h}$ reduced the respiration rate from $1200-2000 \mathrm{~h}$ and rectal temperature from 1300 $1700 \mathrm{~h}$ compared with those without sprinkling (156). MarcillacEmbertson et al. (157) compared the effect of two heat abatement approaches (shade vs. sprinkling) on physiology and growth of Holstein heifers housed in drylot corrals during the summer in California. The shade structures were made of solid metal sheets providing $6.5 \mathrm{~m}^{2}$ of shade per animal, and the sprinklers were activated $7 \mathrm{~min}$ every $2 \mathrm{~h}$ from 1,100 to $1,900 \mathrm{~h}$. Compared with heifers that received sprinkling, shaded heifers had lower respiration rate, similar rectal temperature, but greater intake, average daily gain and feed efficiency. Heat abatement (i.e., shade) for growing heifers seems to be effective to reduce the thermal load of animals and improve growth performance. If extensive heat abatement such as evaporative cooling consisting of fans and sprinklers/misters would further improve the performance and future productivity (i.e., milk yield) of dairy heifers is not clear but deserves further investigation.

\section{SUMMARY AND CONCLUSIONS}

Climate change characterized by a gradual incline in global temperature and frequent occurrence of extreme weather events is becoming a global issue that has significant impacts on performance and welfare of dairy cattle. In addition to impairment of lactational performance, heat stress has substantial impacts on a dairy cow's immune function and health at all stages of her life cycle. During lactation, the summer season is associated with increased disease incidence in cows, which may partially result from reduced immune cell function under heat stress. Recent studies provide solid evidence that dry period heat stress has significant negative effects on innate and adaptive immune function of both the 
dam and the offspring, influencing the morbidity and mortality of early lactation cows and calves from birth to first calving. Heat stress also has direct impacts on passive and cellmediated immunity of neonatal calves, which again may explain increased mortality of calves during summer. Growing heifers have reductions in growth performance during hot weather, but significant impacts of hyperthermia on heifer immune function is not conclusive. Certainly, more research is required in this area.

Heat abatement by physical modification of the environment is effective and profitable to manage heat stress in dairy cattle and is the most successful way to minimize the negative impacts of heat stress on animal health. Although heat abatement for mature dairy cows, especially those housed in barns, has been extensively studied, additional effort is needed to develop effective and

\section{REFERENCES}

1. Fuquay JW. Heat stress as it affects animal production. J Anim Sci. (1981) 51:164-74. doi: $10.2527 /$ jas $1981.521164 \mathrm{x}$

2. Kadzere CT, Murphy MR, Silanikove N, Maltz E. Heat stress in lactating dairy cows: a review. Livest Prod Sci. (2002) 77:59-91. doi: 10.1016/S0301-6226(01)00330-X

3. Collier RJ, Gebremedhin KG. Thermal biology of domestic animals. Annu. Rev. Anim. Biosci. (2015) 3:513-32. doi: 10.1146/annurev-animal-022114-110659

4. Dikmen S, Hansen PJ. Is the temperature-humidity index the best indicator of heat stress in lactating dairy cows in a subtropical environment? J Dairy Sci. (2009) 92:109-16. doi: 10.3168/jds.2008-1370

5. Choshniak I, Jenkinson DM, Blatchford DR, Peaker M. Blood flow and catecholamine concentration in bovine and caprine skin during thermal sweating. Comp Biochem Physiol. (1982) 71C:37-42. doi: 10.1016/0306-4492(82)90007-7

6. Maia ASC, daSilva RG, Battiston Loureiro CM. Sensible and latent heat loss from the body surface of Holstein cows in a tropical environment. Int $J$ Biometeorol. (2005) 50:17-22. doi: 10.1007/s00484-005-0267-1

7. Berman A. Estimates of heat stress relief needs for Holstein dairy cows. $J$ Anim Sci. (2005) 83:1377-84. doi: 10.2527/2005.8361377x

8. Cooke RF. Effects on animal health and immune function. Vet Clin North Am Food Anim Pract. (2019) 35:331-41. doi: 10.1016/j.cvfa.2019.02.004

9. Holsapple MP, West LJ, Landreth KS. Species comparison of anatomical and functional immune system development. Birth Defects Res B Dev Reprod Toxicol. (2003) 68:321-34. doi: 10.1002/bdrb.10035

10. Chase CC, Hurley DJ, Reber AJ. Neonatal immune development in the calf and its impact on vaccine response. Vet Clin North Am Food Anim Pract. (2008) 24:87-104. doi: 10.1016/j.cvfa.2007.11.001

11. Schultz RD, Dunne HW, Heist CE. Ontogeny of the bovine immune response. Infect Immun. (1973) 7:981-91. doi: 10.1128/IAI.7.6.981-991.1973

12. Barrington GM, Parish SM. Bovine neonatal immunology. Vet Clin North Am Food Anim Pract. (2001) 17:463-76. doi: 10.1016/S0749-0720(15)30001-3

13. Wilson RA, Zolnai A, Rudas P, Frenyo LV. T-cell subsets in blood and lymphoid tissues obtained from fetal calves, maturing calves, and adult bovine. Vet Immunol Immunopathol. (1996) 53:49-60. doi: 10.1016/0165-2427(95) 05543-6

14. Charleston B, Fray MD, Baigent S, Carr BV, Morrison WI. Establishment of persistent infection with non-cytopathic bovine viral diarrhoea virus in cattle is associated with a failure to induce type I interferon. J Gen Virol. (2001) 82:1893-7. doi: 10.1099/0022-1317-82-8-1893

15. Senogles DR, Paul PS, Johnson DW, Muscoplat CC. Ontogeny of T cells, B cells and monocytes in the bovine foetus. Clin Exp Immunol. (1979) 36:2 99-303. affordable cooling strategies for grazing dairy cattle, preweaned calves, and growing heifers to maintain immune function and optimal performance of these animals under field conditions.

\section{AUTHOR CONTRIBUTIONS}

GD, ST, and JL have contributed equally and made substantial, direct and intellectual contributions to the work, and approved it for publication.

\section{FUNDING}

Support for research in the author's laboratories was provided by the USDA-NIFA through foundational awards \#2015-6701523409 (GD) and \#2019-67015-29445 (JL).

16. Kampen AH, Olsen I, Tollersrud T, Storset AK, Lund A. Lymphocyte subpopulations and neutrophil function in calves during the first 6 months of life. Vet Immunol Immunopathol. (2006) 113:53-63. doi: 10.1016/j.vetimm.2006.04.001

17. Wells SJ, Dargatz DA, Ott SL. Factors associated with mortality to 21 days of life in dairy heifers in the United States. Prevent Vet Med. (1996) 29:9-19. doi: 10.1016/S0167-5877(96)01061-6

18. Quigley JD III, Drewry JJ. Nutrient and immunity transfer from cow to calf pre- and postcalving. J Dairy Sci. (1998) 81:2779-90. doi: 10.3168/jds.S0022-0302(98)75836-9

19. Clover CK, Zarkower A. Immunologic responses in colostrum-fed and colostrum-deprived calves. Am J Vet Res. (1980) 41:1002-7.

20. Husband AJ, Lascelles AK. Antibody responses to neonatal immunisation in calves. Res Vet Sci. (1975) 18:201-7. doi: 10.1016/S0034-5288(18)33614-2

21. Godden S. Colostrum management for dairy calves. Vet Clin North Am Food Anim Pract. (2008) 24:19-39. doi: 10.1016/j.cvfa.2007.10.005

22. Barker DJ, Winter PD, Osmond C, Margetts B, Simmonds SJ. Weight in infancy and death from ischaemic heart disease. Lancet. (1989) 2:577-80. doi: 10.1016/S0140-6736(89)90710-1

23. Barker DJ. The fetal and infant origins of adult disease. BMJ. (1990) 301:1111. doi: 10.1136/bmj.301.6761.1111

24. Reynolds LP, Borowicz PP, Caton JS, Crouse MS, Dahlen CR, Ward AK. Developmental programming of fetal growth and development. Vet Clin North Am Food Anim Pract. (2019) 35:229-47. doi: 10.1016/j.cvfa.2019.02.006

25. Du M, Tong J, Zhao J, Underwood KR, Zhu M, Ford SP, et al. Fetal programming of skeletal muscle development in ruminant animals. J Anim Sci. (2010) 88:E51-60. doi: 10.2527/jas.2009-2311

26. Reynolds LP, Caton JS. Role of the pre- and post-natal environment in developmental programming of health and productivity. Mol Cell Endocrinol. (2012) 354:54-9. doi: 10.1016/j.mce.2011.11.013

27. Funston RN, Larson DM, Vonnahme KA. Effects of maternal nutrition on conceptus growth and offspring performance: implications for beef cattle production. J Anim Sci. (2010) 13:E205-15. doi: 10.2527/jas.2009-2351

28. West JW. Effects of heat-stress on production in dairy cattle. J Dairy Sci. (2003) 86:2131-44. doi: 10.3168/jds.S0022-0302(03)73803-X

29. Polsky L, von Keyserlingk MAG. Invited review: effects of heat stress on dairy cattle welfare. J Dairy Sci. (2017) 100:8645-57. doi: 10.3168/jds.2017-12651

30. Schröder HJ, Power GG. Engine and radiator: fetal and placental interactions for heat dissipation. Exp Physiol. (1997) 82:403-14. doi: 10.1113/expphysiol.1997.sp004035

31. Faurie AS, Mitchell D, Laburn HP. Feto-maternal relationships in goats during heat and cold exposure. Exp Physiol. (2001) 86:199-204. doi: 10.1113/eph8602152

32. Laburn HP, Faurie A, Goelst K, Mitchell D. Effects on fetal and maternal body temperatures of exposure of pregnant ewes to heat, cold, and exercise. J Appl Physiol. (2002) 92:802-8. doi: 10.1152/japplphysiol.00109.2001 
33. Tao S, Dahl GE. Invited review: heat stress effects during late gestation on dry cows and their calves. J Dairy Sci. (2013) 96:4079-93. doi: $10.3168 /$ jds.2012-6278

34. Edwards MJ, Saunders RD, Shiota K. Effects of heat on embryos and foetuses. Int J Hyperthermia. (2003) 19:295-324. doi: 10.1080/0265673021000039628

35. Merlot E, Couret D, Otten W. Prenatal stress, fetal imprinting and immunity. Brain Behav Immun. (2008) 22:42-51. doi: 10.1016/j.bbi.2007.05.007

36. Sakatani M. Effects of heat stress on bovine preimplantation embryos produced in vitro. J Reprod Dev. (2017) 63:347-52. doi: 10.1262/jrd.2017-045

37. Dutt RH. Critical period for early embryo mortality in ewes exposed to high ambient temperature. J Anim Sci. (1963) 22:713-9. doi: $10.2527 /$ jas $1963.223713 \mathrm{x}$

38. Biggers BG, Geisert RD, Wetteman RP, Buchanan DS. Effect of heat stress on early embryonic development in the beef cow. J Anim Sci. (1987) 64:1512-8. doi: $10.2527 /$ jas1987.6451512x

39. Ealy AD, Drost M, Hansen PJ. Developmental changes in embryonic resistance to adverse effects of maternal heat stress in cows. J Dairy Sci. (1993) 76:2899-905. doi: 10.3168/jds.S0022-0302(93)77629-8

40. Brown BM, Stallings JW, Clay JS, Rhoads ML. Heat stress of Holstein dams is associated with differences in daughter milk production during their first lactation. PLOS ONE. (2016) 11:e0148234. doi: 10.1371/journal.pone.0148234

41. Robinson JJ, McDonald I, Fraser C, Crofts RMJ. Studies on reproduction in prolific ewes: I. Growth of the products of conception. J Agric Sci. (1977) 88:539-52. doi: 10.1017/S0021859600037229

42. Beach RS, Gershwin ME, Hurley LS. Gestational zinc deprivation in mice: persistence of immunodeficiency for three generations. Science. (1982) 218:469-71. doi: 10.1126/science.7123244

43. Veru F, Laplante DP, Luheshi G, King S. Prenatal maternal stress exposure and immune function in the offspring. Stress. (2014) 17:133-48. doi: $10.3109 / 10253890.2013 .876404$

44. Matthews SG. Early programming of the hypothalamo-pituitaryadrenal axis. Trends Endocrinol Metab. (2002) 13:373-80. doi: 10.1016/S1043-2760(02)00690-2

45. Tuchscherer M, Kanitz E, Otten W, Tuchscherer A. Effects of prenatal stress on cellular and humoral immune responses in neonatal pigs. Vet Immunol Immunopathol. (2002) 86:195-203. doi: 10.1016/S0165-2427(02)00035-1

46. Emack J, Kostaki A, Walker CD, Matthews SG. Chronic maternal stress affects growth, behaviour and hypothalamo-pituitary-adrenal function in juvenile offspring. Horm Behav. (2008) 54:514-20. doi: 10.1016/j.yhbeh.2008.02.025

47. Haussmann MF, Carroll JA, Weesner GD, Daniels MJ, Matteri RL, Lay DC Jr. Administration of ACTH to restrained, pregnant sows alters their pigs' hypothalamic-pituitary-adrenal (HPA) axis. J Anim Sci. (2000) 78:2399-411. doi: $10.2527 / 2000.7892399 x$

48. Chapel NM, Byrd CJ, Lugar DW, Morello GM, Baumgard LH, Ross JW, et al. Determining the effects of early gestation in utero heat stress on postnatal fasting heat production and circulating biomarkers associated with metabolism in growing pigs. J Anim Sci. (2017) 95:3914-21. doi: $10.2527 /$ jas 2017.1730

49. Johnson JS, Sanz-Fernandez MV, Patience JF, Ross JW, Gabler NK, Lucy MC, et al. Effects of in utero heat stress on postnatal body composition in pigs: II. Finishing phase. J Anim Sci. (2015) 93:82-92. doi: 10.2527/jas.2014-8355

50. Wu G, Bazer FW, Wallace JM, Spencer TE. Board-invited review: intrauterine growth retardation: implications for the animal sciences. J Anim Sci. (2006) 84:2316-37. doi: 10.2527/jas.2006-156

51. Tao S, Monteiro AP, Thompson IM, Hayen MJ, Dahl GE. Effect of lategestation maternal heat stress on growth and immune function of dairy calves. J Dairy Sci. (2012) 95:7128-36. doi: 10.3168/jds.2012-5697

52. Laporta J, Fabris TF, Skibiel AL, Powell JL, Hayen MJ, Horvath K, et al. In utero exposure to heat stress during late gestation has prolonged effects on the activity patterns and growth of dairy calves. J Dairy Sci. (2017) 100:2976-84. doi: 10.3168/jds.2016-11993

53. Nardone A, Lacetera N, Bernabucci U, Ronchi B. Composition of colostrum from dairy heifers exposed to high air temperatures during late pregnancy and the early postpartum period. $J$ Dairy Sci. (1997) 80:838-44. doi: 10.3168/jds.S0022-0302(97) 76005-3
54. Adin G, Gelman A, Solomon R, Flamenbaum I, Nikbachat M, Yosef E, et al. Effects of cooling dry cows under heat load conditions on mammary gland enzymatic activity, intake of food water, and performance during the dry period and after parturition. Livest Sci. (2009) 124:189-95. doi: 10.1016/j.livsci.2009.01.014

55. Monteiro APA, Tao S, Thompson IM, Dahl GE. Effect of heat stress during late gestation on immune function and growth performance of calves: isolation of altered colostral and calf factors. J Dairy Sci. (2014) 97:6426-39. doi: $10.3168 /$ jds.2013-7891

56. Skibiel AL, Fabris TF, Corra FN, Torres YM, McLean DJ, Chapman JD, et al. Effects of feeding an immunomodulatory supplement to heatstressed or actively cooled cows during late gestation on postnatal immunity, health, and growth of calves. J Dairy Sci. (2017) 100:7659-68. doi: 10.3168/jds.2017-12619

57. Ahmed BMS. Elevated in utero temperature: a suppressor of fetal developmentruminant fitness? (Ph.D. Dissertation). University of Florida, Gainesville, FL, United States (2017).

58. Castro-Alonso A, Castro N, Capote J, Morales-delaNuez A, Moreno-Indias I, Sánchez-Macias D, et al. Short communication: apoptosis regulates passive immune transfer in newborn kids. J Dairy Sci. (2008) 91:2086-8. doi: 10.3168/jds.2007-0814

59. Koch F, Thom U, Albrecht E, Weikard R, Nolte W, Kuhla B, et al. Heat stress directly impairs gut integrity and recruits distinct immune cell populations into the bovine intestine. Proc Natl Acad Sci USA. (2019) 116:10333-8. doi: 10.1073/pnas.1820130116

60. Pearce SC, Mani V, Weber TE, Rhoads RP, Patience JF, Baumgard LH, et al. Heat stress and reduced plane of nutrition decreases intestinal integrity and function in pigs. J Anim Sci. (2013) 91:5183-93. doi: 10.2527/jas.2013-6759

61. Dokladny K, Moseley PL, Ma TY. Physiologically relevant increase in temperature causes an increase in intestinal epithelial tight junction permeability. Am J Physiol Gastrointest Liver Physiol. (2006) 290:G204-12. doi: 10.1152/ajpgi.00401.2005

62. Strong RA, Silva EB, Cheng HW, Eicher SD. Acute brief heat stress in late gestation alters neonatal calf innate immune functions. J Dairy Sci. (2015) 98:7771-83. doi: 10.3168/jds.2015-9591

63. Langley-Evans SC. Developmental programming of health and disease. Proc Nutr Soc. (2006) 65:97-105. doi: 10.1079/PNS2005478

64. Collier RJ, Doelger SG, Head HH, Thatcher WW, Wilcox CJ. Effects of heat stress during pregnancy on maternal hormone concentrations, calf birth weight and postpartum milk yield of Holstein cows. J Anim Sci. (1982) 54:309-19. doi: 10.2527/jas1982.542309x

65. do Amaral BC, Connor EE, Tao S, Hayen J, Bubolz J, Dahl GE. Heatstress abatement during the dry period: does cooling improve transition into lactation? J Dairy Sci. (2009). 92:5988-99. doi: 10.3168/jds.2009-2343

66. Fabris TF, Laporta J, Skibiel AL, Corra FN, Senn BD, Wohlgemuth SE, et al. Effect of heat stress during early, late, and entire dry period on dairy cattle. $J$ Dairy Sci. (2019) 102:5647-56. doi: 10.3168/jds.2018-15721

67. Potadle GM, Dahl GE, Dado-Senn B, Laporta J, Bundy J, Tyler HD. Effect of placental parameters on dairy calf performance. In: Proceedings of the 8 th Perinatal Biology Symposium. Snowmass, CO (2019). p. 36.

68. Regnault TRH, de Vrijer B, Galan HL, Davidsen ML, Trembler KA, Battaglia FC, et al. The relationship between transplacental O2 diffusion and placental expression of PIGF, VEGF and their receptors in a placental insufficiency model of fetal growth restriction. J Physiol. (2003) 550:641-56. doi: 10.1113/jphysiol.2003.0 39511

69. Dreiling CE, Carman FS III, Brown, DE. Maternal endocrine and fetal metabolic responses to heat stress. J Dairy Sci. (1991) 74:312-27. doi: 10.3168/jds.S0022-0302(91)78175-7

70. Skibiel AL, Peñagaricano F, Amorín R, Ahmed BM, Dahl GE, Laporta J. In utero heat stress alters the offspring epigenome. Sci Rep. (2018) 8:14609. doi: 10.1038/s41598-018-32975-1

71. Tröger B, Müller T, Faust K, Bendiks M, Bohlmann MK, Thonnissen S, et al. Intrauterine growth restriction and the innate immune system in preterm infants of $\leq 32$ weeks gestation. Neonatology. (2013) 103:199-204. doi: $10.1159 / 000343260$

72. Dong L, Zhong X, Ahmad H, Li W, Wang Y, Zhang L, et al. Intrauterine growth restriction impairs small intestinal mucosal 
immunity in neonatal piglets. J Histochem Cytochem. (2014) 62:510-8. doi: $10.1369 / 0022155414532655$

73. Contreras YM, Yu X, Hale MA, Callaway CW, Bareyan D, McKnight RA, et al. Intrauterine growth restriction alters T-lymphocyte cell number and dual specificity phosphatase 1 levels in the thymus of newborn and juvenile rats. Pediatr Res. (2011) 70:123-9. doi: 10.1203/PDR.0b013e31821f6e75

74. Monteiro APA, Tao S, Thompson IM, Dahl GE. In utero heat stress decreases calf survival and performance through the first lactation. J Dairy Sci. (2016) 99:8443-50. doi: 10.3168/jds.2016-11072

75. Laporta J, Ferreira FC, Dado-Senn B, De Vries A, Dahl GE. Dry period heat stress reduces dam, daughter,grand-daughter productivity. J. Dairy Sci. (2018) 101(Suppl. 2):151.

76. Sanders VM. Epigenetic regulation of th1 and th2 cell development. Brain Behav Immun. (2016) 20:317-24. doi: 10.1016/j.bbi.2005. 08.005

77. Stull C, Reynolds J. Calf welfare. Vet Clin North Am Food Anim Pract. (2008) 24:191-203. doi: 10.1016/j.cvfa.2007.12.001

78. Zhai R, Dong X, Feng L, Li S, Hu Z. The effect of heat stress on autophagy and apoptosis of rumen, abomasum, duodenum, liver and kidney cells in calves. Animals. (2019) 9:854. doi: 10.3390/ani9100854

79. Roland L, Drillich M, Klein-Jöbstl D, Iwersen M. Invited review: influence of climatic conditions on the development, performance, and health of calves. $J$ Dairy Sci. (2016) 99:2438-52. doi: 10.3168/jds.2015-9901

80. Neuwirth JG, Norton JK, Rawlings CA, Thompson FN. Physiologic responses of dairy calves to environmental health stress. Int J Biometeorol. (1979) 23:243-54. doi: 10.1007/BF01553775

81. Stull CL, Messam LLM, Collar CA, Peterson NP, Reed BA, Anderson $\mathrm{KL}$, et al. Precipitationtemperature effects on mortalitylactation parameters of dairy cattle in Cali-fornia. J Dairy Sci. (2008) 91:4579-91. doi: $10.3168 /$ jds.2008-1215

82. Heinrichs AJ, Heinrichs BS, Harel O, Rogers GW, Place NT. A prospective study of calf factors affecting age, body size, and body condition score at first calving of holstein dairy heifers. J Dairy Sci. (2005) 88:2828-35. doi: 10.3168/jds.S0022-0302(05)72963-5

83. Kelly DW, Osborne CA, Evermann JF, Parish SM, Gaskins CT. Effects of chronic heat and cold stressors on plasma immunoglobulin and mitogen-induced blastogenesis in calves. J Dairy Sci. (1982) 65:1514-28. doi: 10.3168/jds.S0022-0302(82)82376-X

84. Srikanth K, Kwon A, Lee E, Chung H. Characterization of genes and pathways that respond to heat stress in holstein calves through transcriptome analysis. Cell Stress Chaperones. (2017) 22:29-42. doi: 10.1007/s12192-016-0739-8

85. Cui Y, Hao Y, Li J, Bao W, Li G, Gao Y, et al. Chronic heat stress induces immune response, oxidative stress response, and apoptosis of finishing pig liver: a proteomic approach. Int. J Mol. Sci. (2016) 17:393. doi: 10.3390/ijms17050393

86. Morrow-Tesch JL, McGlone JJ, Salak-Johnson JL. Heat and social stress effects on pig immune measures. J Anim Sci. (1994) 72:2599-609. doi: $10.2527 / 1994.72102599 \mathrm{x}$

87. United States Department of Agriculture Animal and Plant Health Inspection Service. Dairy Cattle Management Practices in the United States, 2014 (2016)

88. Svensson C, Linder A, Olsson S-O. Mortality in Swedish dairy calves and replacement heifers. I Dairy Sci. (2006) 89:4769-77. doi: 10.3168/jds.S0022-0302(06) 72526-7

89. Windeyer MC, Leslie KE, Godden SM, Hodgins DC, Lissemore KD, LeBlanc SJ. The effects of viral vaccination of dairy heifer calves on the incidence of respiratory disease, mortality, and growth. J Dairy Sci. (2012) 95:6731-9. doi: $10.3168 /$ jds.2012-5828

90. Kibler HH. Environmental physiology and shelter engineering LXI: energy metabolism and related thermoregulatory reactions to thermal stress in $50^{\circ}$ and $80^{\circ}$ acclimated dairy heifers. Missouri Agric Exp Stn Res Bull. (1962) 793:1-33.

91. Kibler HH. Environmental physiology and shelter engineering LV: Energy metabolism and related thermoregulatory reactions in Brown Swiss, Holstein, and Jersey calves during growth at $50^{\circ}$ and $80^{\circ} \mathrm{F}$ temperatures. Missouri Agric Exp Stn Res Bull. (1960) 743:1-38.
92. Johnson HD, Ragsdale AC. Environmental physiology and shelter engineering LXII: Surface area determinations of beef and dairy calves during growth at $50^{\circ}$ and $80^{\circ}$ environmental temperatures. Missouri Agric Exp Stn Res Bull. (1961) 770:1-27.

93. Kamwanja LA, Chase CC Jr, Gutierrez JA, Guerriero V Jr, Olsen TA, Hammond AC, et al. Responses of bovine lymphocytes to heat shock as modified by breedantioxidant status. J Anim Sci. (1994) 72:438-44. doi: $10.2527 / 1994.722438 \mathrm{x}$

94. Carroll JA, Burdick-Sanchez NC, Chaffin R, Chase CC Jr, Coleman SW, Spiers DE. Heat-tolerant versus heat-sensitive Bos Taurus cattle: influence of air temperature and breed on the acute phase response to a provocative immune challenge. Domest Anim Endocrinol. (2013) 45:163-9. doi: 10.1016/j.domaniend.2013.08.002

95. Burke NC, Scaglia G, Saker KE, Blodgett DJ, Swecker WS Jr. Influence of endophyte consumption and heat stress on intravaginal temperatures, plasma lipid oxidation, blood selenium, and glutathione redox of mononuclear cells in heifers grazing tall fescue. J Anim Sci. (2007) 85:293240. doi: $10.2527 /$ jas.2007-0303

96. Mitlöhner FM, Galyean ML, McGlone JJ. Shade effects on performance, carcass traits, physiology, and behavior of heat-stressed feedlot heifers. $J$ Anim Sci. (2002) 80:2043-50. doi: 10.2527/2002.8082043x

97. Elvinger F, Hansen PJ, Natzke RP. Modulation of function of bovine polymorphonuclear leukocytes and lymphocytes by high temperature in vitro and in vivo. Am J Vet Res. (1991) 52:1692-8.

98. Nickerson SC, Owens WE, Boddie RL. Mastitis in dairy heifers: initial studies on prevalence and control. J Dairy Sci. (1995) 78:1607-18. doi: 10.3168/jds.S0022-0302(95)76785-6

99. Akers RM. Milking management. In: Lactation and the Mammary Gland. Ames, IA: Iowa State Press (2002). p. 105-28. doi: 10.1002/9781119264880.ch5

100. Zeinhom MM, Abdel Aziz RL, Mohammed AN, Bernabucci U. Impact of seasonal conditions on quality and pathogens content of milk in Friesian cows. Asian-Australas J Anim Sci. (2016) 29:1207-13. doi: 10.5713 /ajas. 16.0143

101. Lambertz C, Sanker C, Gauly M. Climatic effects on milk production traits and somatic cell score in lactating Holstein-Friesian cows in different housing systems. J Dairy Sci. (2014) 97:319-29. doi: 10.3168/jds.2013-7217

102. Nasr MA, El-Tarabany MS. Impact of three THI levels on somatic cell count, milk yield and composition of multiparous Holstein cows in a subtropical region. J Therm Biol. (2017) 64:73-7. doi: 10.1016/j.jtherbio.2017.01.004

103. Lundberg ̊̊, Nyman AK, Aspán A, Börjesson S, Unnerstad HE, Waller KP. Udder infections with Staphylococcus aureus, Streptococcus dysgalactiae, and Streptococcus uberis at calving in dairy herds with suboptimal udder health. $J$ Dairy Sci. (2016) 99:2102-17. doi: 10.3168/jds.2015-9487

104. Safa S, Kargar S, Moghaddam GA, Ciliberti MG, Caroprese M. Heat stress abatement during the postpartum period: effects on whole lactation milk yield, indicators of metabolic status, inflammatory cytokines, and biomarkers of the oxidative stress. J Anim Sci. (2019) 97:122-32. doi: 10.1093/jas/sky408

105. DuBois PR, Williams DJ. Increased incidence of retained placenta associated with heat stress in dairy cows. Theriogenology. (1980) 13:115-21. doi: 10.1016/0093-691X(80)90120-X

106. Gernand E, König S, Kipp C. Influence of on-farm measurements for heat stress indicators on dairy cow productivity, female fertility, and health. $J$ Dairy Sci. (2019) 102:6660-71. doi: 10.3168/jds.2018-16011

107. Molinari PCC, Sheldon IM, Dahl GE, Bromfield JJ. Regardless of bacterial load in the vagina, heat stress increases uterine disease incidenceseverity in the dairy cow. J. Dairy Sci. (2019). 102(Suppl. 1):306.

108. Molinari PCC, Sheldon IM, Bromfield JJ. Heat stress increases the incidence of uterine disease in dairy cattle without affecting the vaginal bacteria load. S17.4. In: Society for the Study of Reproduction 52nd Annual Conference. San Jose, CA (2019). p. 41.

109. Lacetera N, Bernabucci U, Scalia D, Basiricò L, Morera P, Nardone A. Heat stress elicits different responses in peripheral blood mononuclear cells from brown swiss and holstein cows. J Dairy Sci. (2006) 89:4606-12. doi: 10.3168/jds.S0022-0302(06)72510-3

110. Lecchi C, Rota N, Vitali A, Ceciliani F, Lacetera N. In vitro assessment of the effects of temperature on phagocytosis, reactive oxygen species production and apoptosis in bovine polymorphonuclear cells. Vet 
Immunol Immunopathol. (2016) 182:89-94. doi: 10.1016/j.vetimm.2016. 10.007

111. Dingwell RT, Kelton DF, Leslie KE. Management of the dry cow in control of peripartum disease and mastitis. Vet Clin North Am Food Anim Pract. (2003) 19:235-65. doi: 10.1016/S0749-0720(02)00072-5

112. Oliver SP, Mitchell BA. Susceptibility of bovine mammary gland to infections during the dry period. J Dairy Sci. (1983) 66:1162-6. doi: $10.3168 /$ jds.S0022-0302(83)81913-4

113. Olde Riekerink RG, Barkema HW, Stryhn H. The effect of season on somatic cell count and the incidence of clinical mastitis. J Dairy Sci. (2007) 90:1704-15. doi: 10.3168/jds.2006-567

114. Lacetera N, Bernabucci U, Ronchi B, Scalia D, Nardone A. Moderate summer heat stress does not modify immunological parameters of holstein dairy cows. Int J Biometeorol. (2002) 46:33-7. doi: 10.1007/s00484-001-0115-x

115. do Amaral BC, Connor EE, Tao S, Hayen MJ, Bubolz JW, Dahl GE. Heat stress abatement during the dry period influences prolactin signaling in lymphocytes. Domest Anim Endocrinol. (2010) 38:38-45. doi: 10.1016/j.domaniend.2009.07.005

116. do Amaral BC, Connor EE, Tao S, Hayen MJ, Bubolz JW, Dahl GE. Heat stress abatement during the dry period influences metabolic gene expressionimproves immune status in the transition period of dairy cows. J. Dairy Sci. (2011) 94:86-96. doi: 10.3168/jds.2009-3004

117. Thompson IM, Tao S, Monteiro AP, Jeong KC, Dahl GE. Effect of cooling during the dry period on immune response after Streptococcus uberis intramammary infection challenge of dairy cows. J Dairy Sci. (2014) 97:742636. doi: 10.3168/jds.2013-7621

118. Thompson IM, Dahl GE. Dry period seasonal effects on the subsequent lactation. Prof Anim Sci. (2012) 28:628-31. doi: 10.15232/S1080-7446(15)30421-6

119. Beede DK, Collier RJ. Potential nutritional strategies for intensively managed cattle during thermal stress. J Anim Sci. (1986) 62:543-54. doi: $10.2527 /$ jas $1986.622543 x$

120. Collier RJ, Baumgard LH, Zimbelman RB, Xiao Y. Heat stress: physiology of acclimation and adaptation. Anim Front. (2019) 9:12-9. doi: $10.1093 / \mathrm{af} / \mathrm{vfy} 031$

121. Rhoads RP, Baumgard LH, Suagee JK, Sanders SR. Nutritional interventions to alleviate the negative consequences of heat stress. Adv Nutr. (2013) 4:267-76. doi: 10.3945/an.112.003376

122. Gunn KM, Holly MA, Veith TL, Buda AR, Prasad R, Rotz CA, et al. Projected heat stress challengesabatement opportunities for U.S. milk production. PLoS ONE. (2019) 14:e0214665. doi: 10.1371/journal.pone.02 14665

123. Armstrong DV. Heat stress interaction with shade and cooling. J Dairy Sci. (1994) 77:2044-50. doi: 10.3168/jds.S0022-0302(94)77149-6

124. Collier RJ, Dahl GE, Vanbaale MJ. Major advances associated with environmental effects on dairy cattle. J Dairy Sci. (2006) 89:1244-53. doi: $10.3168 /$ jds.S0022-0302(06)72193-2

125. Zimbleman RB, Rhoads RP, Baumgard LH, Collier RJ. Revised temperature humidity index (THI) for high producing dairy cows. J Dairy Sci. (2009) 92:347.

126. IUPS Thermal Commission. Glossary of terms for thermal physiology Third edition. Jpn J Physiol. (2001). 51:245-80. Available online at: https:// iss.ndl.go.jp/books/R100000002-I000000120340-00

127. Roman-Ponce H, Thatcher WW, Wilcox CJ. Hormonal interrelationships and physiological responses of lactating dairy cows to a shade management system in a subtropical environment. Theriogenology. (1981) 16:139-54. doi: 10.1016/0093-691X(81)90097-2

128. Collier RJ, Beede DK, Thatcher WW, Israel LA, Wilcox CJ. Influences of environment and its modification on dairy animal health and production. J Dairy Sci. (1982) 65:2213-27. doi: 10.3168/jds.S0022-0302(82)82484-3

129. Palacio S, Bergeron R, Lachance S, Vasseur E. The effects of providing portable shade at pasture on dairy cow behavior and physiology. J Dairy Sci. (2015) 98:6085-93. doi: 10.3168/jds.2014-8932

130. Kendall PE, Nielsen PP, Webster JR, Verkerk GA, Littlejohn RP, Mathews LR. The effects of providing shade to lactating dairy cows in a temperate climate. Livest Sci. (2006) 103:148-57. doi: 10.1016/j.livsci.2006.02.004

131. van laer E, Tuyttens FAM, Ampe B, Sonck B, Moons CPH, Vandaele L. Effect of summer conditions and shade on the production and metabolism of Holstein dairy cows on pasture in temperate climate. Animal. (2015) 9:1547-58. doi: 10.1017/S1751731115000816

132. Renaudeau D, Collin A, Yahav S, de Basilio V, Gourdine JL, Collier RJ. Adaptation to hot climate and strategies to alleviate heat stress in livestock production. Animal. (2012) 6:707-28. doi: 10.1017/S175173111 1002448

133. Fournel S, Ouellet V, Charbonneau É. Practices for alleviating heat stress of dairy cows in humid continental climates: a literature review. Animals. (2017) 7:E37. doi: 10.3390/ani7050037

134. Brouk MJ, Harner JP, Smith JF, Hammond AK, Miller WF, Park AF. Effect of soaking and misting on respiration rate, body surface temperature, and body temperature of heat stressed dairy cattle. Kansas Agric Exp Stn Res Report. (2003) 12-16. doi: 10.4148/2378-5977.3210

135. Weng XS, Monteiro APA, Guo JR, Li C, Orellana RM, Marins TN, et al. Effects of heat stress and dietary zinc source on mammary epithelial integrity of lactating dairy cows. J Dairy Sci. (2018) 101:2617-30. doi: $10.3168 /$ jds.2017-13484

136. Brouk MJ, Harner JP III, Smith JF, Miller WF, Cvetkovic B. Impact of air velocitydirection of flow upon respiration rate, body surface temperaturebody temperature of heat stressed dairy cattle. J. Dairy Sci. (2004). 87:300.

137. Brouk MJ, Smith JF, Harner JP, DeFrain SE. Effect of fan placement on milk production and dry matter intake of lactating dairy cows housed in a 4-row freestall barn. Kansas Agric Exp Stn Res Report. (2001) 303. doi: $10.4148 / 2378-5977.3228$

138. Calegari F, Calamari L, Frazzi E. Fan cooling of the resting area in a free stalls dairy barn. Int J Biometeorol. (2014) 58:1225-36. doi: 10.1007/s00484-013-0716-1

139. Valtorta SE, Gallardo MR. Evaporative cooling for Holstein dairy cows under grazing conditions. Int J Biometeorol. (2004) 48:213-7. doi: 10.1007/s00484-003-0196-9

140. Gallardo MR, Valtorta SE, Leva PE, Gaggiotti MC, Conti GA, Gregoret RF. Diet and cooling interactions on physiological responses of grazing dairy cows, milk production and composition. Int J Biometeorol. (2005) 50:90-5. doi: 10.1007/s00484-005-0276-0

141. Dikmen S, Martins L, Pontes E, Hansen PJ. Genotype effects on body temperature in dairy cows under grazing conditions in a hot climate including evidence for heterosis. Int J Biometeorol. (2009) 53:327-31. doi: 10.1007/s00484-009-0218-3

142. Gomes CG, Zuniga JE, Karakaya E, Greco LF, Sinedino LDP, Martinez $\mathrm{N}$, et al. Effects of prepartum evaporative cooling and vitamin $\mathrm{E}$ supplementation on immune function of Holstein cows during summer in Florida. J Dairy Sci. (2013) 97:725.

143. Tao S, Bubolz JW, do Amaral BC, Thompson IM, Hayen MJ, Johnson $\mathrm{SE}$, et al. Effect of heat stress during the dry period on mammary gland development. J Dairy Sci. (2011) 94:5976-86. doi: 10.3168/jds.2011 $-4329$

144. Lamb RC, Morrow BK, Arambel M, Arave CW. Comparison of plastic domes with wooden hutches for housing dairy calves. J Dairy Sci. (1987) $70: 145$.

145. Lammers BP, vanKoot JW, Heinrichs AJ, Graves RE. The effect of plywood and polyethylene calf hutches on heat stress. Appl Eng Agric. (1996)12:741-5. doi: $10.13031 / 2013.25707$

146. Peña G, Risco C, Kunihiro E, Thatcher MJ, Pinedo PJ. Effect of housing type on health and performance of preweaned dairy calves during summer in Florida. J Dairy Sci. (2016) 99:1655-62. doi: 10.3168/jds.2015-10164

147. Macaulay AS, Hahn GL, Clark DH, Sisson DV. Comparison of calf housing types and tympanic temperature rhythms in Holstein calves. J Dairy Sci. (1995) 75:856-2. doi: 10.3168/jds.S0022-0302(95)76698-X

148. Manriquez D, Valenzuela H, Paudyal S, Velasquez A, Pinedo PJ. Effect of aluminized reflective hutch covers on calf health and performance. J Dairy Sci. (2018) 101:1464-77. doi: 10.3168/jds.2017-13045

149. Stott GH, Wiersma F, Menefee BE, Radwanski FR. Influence of environment on passive immunity in calves. J Dairy Sci. (1976) 59:1306-11. doi: 10.3168/jds.S0022-0302(76)84360-3

150. Spain JN, Spiers DE. Effects of supple-mental shade on thermoregulatory response of calves to heat challenge in a hutch environ-ment. J Dairy Sci. (1996) 79:639-46. doi: 10.3168/jds.S0022-0302(96)76409-3 
151. Coleman DA, Moss BR, McCaskey TA. Supplemental shade for dairy calves reared in commercial calf hutches in a southern climate. J Dairy Sci. (1996) 79:2038-43. doi: 10.3168/jds.S0022-0302(96)76577-3

152. Kovács L, Kézér FL, Ruff F, Jurkovich V, Szenci O. Assessment of heat stress in 7-week old dairy calves with non-invasive physiological parameters in different thermal environments. PLoS ONE. (2018) 13:e0200622. doi: 10.1371/journal.pone.0200622

153. Moore DA, Duprau JL, Wenz JR. Short communication: effects of dairy calf hutch elevation on heat reduction, carbon dioxide concentration, air circulation, and respiratory rates. J Dairy Sci. (2012) 95:4050-4. doi: $10.3168 /$ jds.2012-5397

154. Hill TM, Bateman HG II, Aldrich JM, Schlotterbeck RL. Comparisons of housing, bedding, and cooling options for dairy calves. J Dairy Sci. (2011) 94:2138-46. doi: 10.3168/jds.2010-3841

155. Dado-Senn B, Vega Acosta L, Torres Rivera M, Field SL, Marrero MG, Tao $S$, et al. Effect of pre-postnatal heat stress on dairy calf thermoregulation productivity. J. Dairy Sci. (in press).
156. Davis S, Mader TL, Gaughan J. Effect of Sprinkling on Heat Stressed Heifers. Nebraska Beef Cattle Reports, University of Nebraska (2002).

157. Marcillac-Embertson NM, Robinson PH, Fadel JG, Mitloehner FM. Effects of shade and sprinklers on performance, behavior, physiology, and the environment of heifers. J Dairy Sci. (2009) 92:506-17. doi: $10.3168 /$ jds.2008-1012

Conflict of Interest: The authors declare previously received study support from Phibro Animal Health (GD, ST, JL) and Zinpro Corp (ST). These funders had no involvement in the conception or writing of this review.

Copyright (C) 2020 Dahl, Tao and Laporta. This is an open-access article distributed under the terms of the Creative Commons Attribution License (CC BY). The use, distribution or reproduction in other forums is permitted, provided the original author(s) and the copyright owner(s) are credited and that the original publication in this journal is cited, in accordance with accepted academic practice. No use, distribution or reproduction is permitted which does not comply with these terms. 